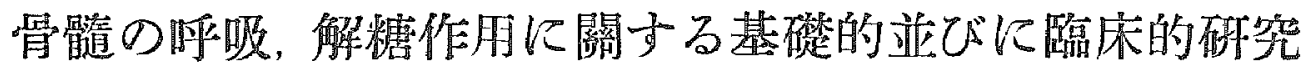

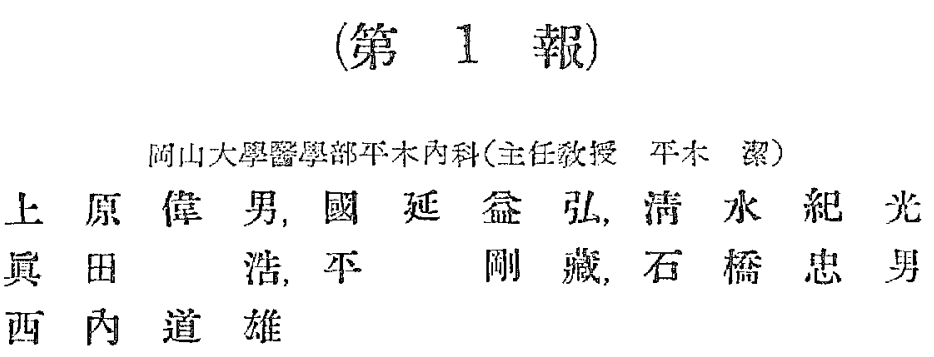

\section{FUNDAMENTAL AND CLINICAL STUDIES ON OXYGEN CONSUMPTION AND GLYCOLYSIS OF BONE MARROW. (1st Report) \\ By}

Hideo Uehara, Masuhiro Kuninobu, Norimitsu Shimizu, Hiroshi Sanada, Gōzō Taira, Tadao Ishibashi, Michio Nishiuchi

Dept. of Internal Medicine, Okayama University Medical School.

(Director: Prof. K. Hiraki)

In estimating oxygen consumption and glycolysis of bone marrow by warburg's apparatus, the method of making slices seems to have much influence upon results. When the obstruction imposed on the tissue proves intense, it is hard to obtain a constant results. We, inserting the tissue of bone marrow between two Graete's messes, and by cutting while smoothly moving these knives on both sides, could succeed in getting thinkness of the slices below $0.5 \mathrm{~mm}$.

In a normal rabbit these slices, of bone marrow have always proved greater amount of oxygen consumption than in case of minced one; besides, the lowering rate according to the lapse of time was smaller. As for the floating solution, relatively constant results were obtained with saline phosphate solution, but Ringer-bicarbonate solution possesses greater value than those of saline phosphate solution or Tyrode's solution, showing slightest in their lowering rate in the course of time. The optimum $\mathrm{pH}$ in the floating solution seems at $\mathrm{pH}$ 7.4.

Subsequently, as for sternal punctate, clinical application would be made possible by making conditions of both puncture as well as suction more steady. Results may need to be judged from all these figures: $\mathrm{Xo}_{3}, \mathrm{Xo}_{2} / \mathrm{K}, \mathrm{Qo}_{2}, \mathrm{X}_{\mathrm{M}}^{\mathrm{N}_{2}}, \mathrm{X}_{\mathrm{M}}^{\mathrm{N}} / \mathrm{K}, \mathrm{Q}_{\mathrm{M}}^{\mathrm{N}},(\mathrm{K}=$ nucleated cells in $1 \mathrm{cmm}$ punctate).

If considered as to various kind of diseases in series of microcytic hypochromic anemia, 
oxygen consumption has indicated approximately normal, or somewhat excessive accompanied with a moderate advance in glycolysis. In case of hypoplastic anemia, the both function lowers remarkably, moreover in the type of blood cell arrest, the lowering ratio proved slight, while proved marked with the type of regeneration disturbance, mixed type or panmyelophtisis. Also, in hypoplastic anemia, $\mathrm{X}_{2}, \mathrm{X}_{\mathrm{M}}^{\mathrm{N}_{2}} / \mathrm{X}$ show pretty high so that it appears almost antipodinous compared to leukemia. Among various leukemias, the rise in oxygen consumption in case of monocytic leukemia appears remarkably unique.

Thus, we could realize that oxygen consumption and glycolsis in the bone marrow possess very close connection with hematopoietic function, playing an important role in the explanation of ethological physiology of bone marrow as well as clinical differential diagnosis.

\section{内容目次}

I 序

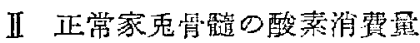

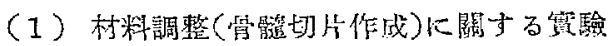

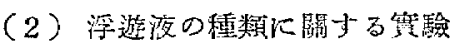

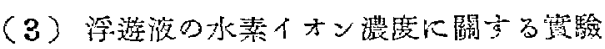

II 臨床的檢桲

（1）胸骨穿刺液老脚以当場合の基礎的事䞍

A 胸骨穿刺方法々呼吸解糖檤

(a) 探取液量上呼吸值

(b) 同一第刺孔に於いて遗續 2 国喛引に上る 埸合の呼吸解糖值

B 健康人胸筒穿刺液の呼吸解糖值

C 胸骨穿刺液の無脂朌乾燥重空と有核細胞数と の關係

（2）各種疾患患者胸骨穿刺液の呼吸解楛值

A 小赤血球性低色菜性貿血

B 再生不良性窝血

C 白血病

D 其他の疾虫

IV 結 論

\section{I 序}

造血䑏器殊に骨䯣の機能檢查に關してはその形 態學的研究に比して業續が比較的少ない.なかん ずく骨膸の組織呼吸立びに解糖能に關する業續は 他の組織或は末梢血細胞等に比して極少な い. 私達は骨䯣の呼吸解猜作用が造血機能に密接

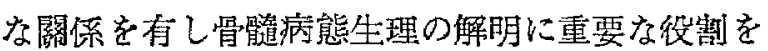

果すものなる点に鑑み，次の譣索劣試みた。

\section{1 正常家鬼骨檤の酸素消費量}

先ず研究方法に關する基磷的檢素として，正学

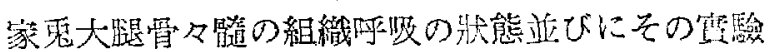
万法に關して檢索し，又從来の諸芜の方法を禞馀 した.

方法は Warburg 檢王計を螣い直接法によつ た。

生後 4〜5力月の体重 $2 \mathrm{~kg}$ 内外の战熟蜼家要 用い, 約10日間一定飼料にて飼壳し, 未梢血液像 を檢查し常に正常である事を雅めたる後，頭部を

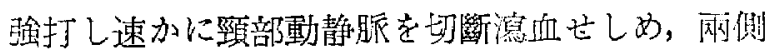
の大擥骨を關節面にて離斷し，下端法雫端線より 骨幹部へ 2〜3 mmの部を，上端は大監骨々䯣主要 榮荃動静脈出入口部を鋸にて骨筫に割線を入れ， 㓶線の部より兩端を折り，下端より重曹を含まな い浮遊液（後述）中に吹き出す，斯くする時は骨

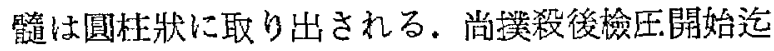
をすへで5分に一定した。䏇脂肪乾燥重量の計測 は内容を $100^{\circ} \mathrm{C}$ 乾燥器中に 3 㭙間乾燥せしぬた後 エーテルを加え，乾燥物を碎粉し一書夜窒温に置 いた後含脂肪エーテルを除去する。このエーテル 抽出操作を更に後 2 国 4 時間宛行なつた後, 塩化 カルシウム除湶器中に重量一定上なる过梖え，化 學天秤にて秤量した。

（1）材料調整(骨髓切片作製法)に閣する實駼 骨髓組織の呼吸，解糖作用はその造血機能と密 
接な關係が想像されるに詞らず他の藏器に比して 檢䕀が遲れているのは，本組織が柔軟洈弱で取扱 い難く, 特に0.5m以下の所謂限界切片厚の得難 いこと，又細胞の破壊など傷䇺に對して鋭敏で一 定の成緹が得難いこと等に原因している。諸家の 方法を檢討してみると骨檤の酸素消費量に關する 最初の報告は Bréza(1926)で彼は Laubsage で樌 にひき，塊は鉱で小さく切り或は分離針で分ける 方法を用いた。藤田は容器內一採つた組織片をピ ペットで攪きまわし，Orr. Sticklandはリンダル

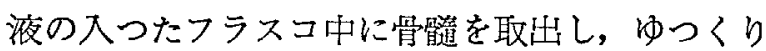
と $2 \sim 3$ 分間振ると速かに正確な代謝を測定する に足る均等な浮遊液となると述べている，Warren は始めパラフィン塊に種々の大きさの内舞を


クロメーターで切つたが，後には浮遊液と共に試 験管内で強く振とうし，镥く遠沈して脂肪細胞を 含を上部を取除いた部分を用い，更にシャーレ内 で潮子二本で細片に分けるのみで同的を達すると 云つた. Goldinger, Lipton, Barron は鎚及は刀 で細片したものをガラスホモギナイザーで擦り， ばらばらになる栐に振り，Cohn，Runjavac, Straus は數包度下用注射器を通すことによつて骨䯣 組織を小さくして用い，津田は細分しておけば檢 圧振とう中に細胞は個々に遊離するから限界切片 厚内に入るものと豫想した。，以上の様に墸家は Warren のミクロメーター法を除いては殆ど縣濁 浮遊液を用い，その操作によって細胞に障害を與 えない様であると述べる者もある。私共も前記諸 家の方法を試みたが細胞破壊の大なる處置を加え る程呼吸能力は制限せられ，又假に細胞の損賃は

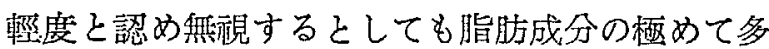
量な本組織では均等な縣濁遊游液とすることは困 難であり，ホモギナイザー使用後の浮遊液は上層 部に脂肪成分の凝固甚しく且つその中に骨䯈細胞 が脂肪によつて取圍まれて介在するのが檢鏡的に 可成り多く談められ，これを取除いた殘りのもの を使用することは骨艏の全組織ではなく，その一 部分が洗い出されたものについて代謝を測定する
ことになると考えられる。かっる觀点から私達は 以下远べる切片法及び销切法によつて得た骨䠄全 組織を材料としてそれぞれ 3 個の容器に採り同様 に檢圧しここの2方法を比較檢討した。

A 切片法: 第1 圖の如く兩手にグレーフェ氏 刀を交叉させて持ち，骨睎組織をはさみ左右に滑 らす様に引きつ>切る. 前述の如く組䋨の酸素消 費量測定に際して切片の作製は特に重要な点であ るが私達は骨䯣に扔いて以上の方法を若策しここ れに䅛熟することによつて比較的容易に限界切片 厚内の骨髓切片を得ることが出来た。

Fig. 1



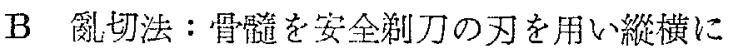
留切し出来る限り細分した。

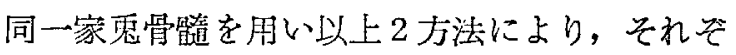
れリンダル重曹液に浮遊せしめ, 10分每の酸素消 費量 $(ー \mathrm{cmm})$ を測定し，各々のエーテル脱脂哕 燥重量で除した值師ち Q02 を測定した。全例を 通じて切片法は镎切法に比して常に高值を示し， 13例の平均は前者は $5.42 \pm 0.253$, 後者は 4.84 土 0.207 で有意の差を認める. 又10分每について比 慗すると第 2 圖の如く亂切法では切片法に比して 時間の經過と共にQ02の減少度が著明である。

以上の成續は筒切法においては切片法に比して 細胞の傷害甚しく，又振とうの初期には材料比 較的均一であるが時間の經過と共に大小不同の凝 塊を形成する事が多く，限界切片厚を淽足しない 場合も生じ，又檢圧中に一部の材料が签器內壁に 
Fig. 2 Oxygen consumption of bone marrow; Sliced and minced tissue. (Average of 13 rabbits)

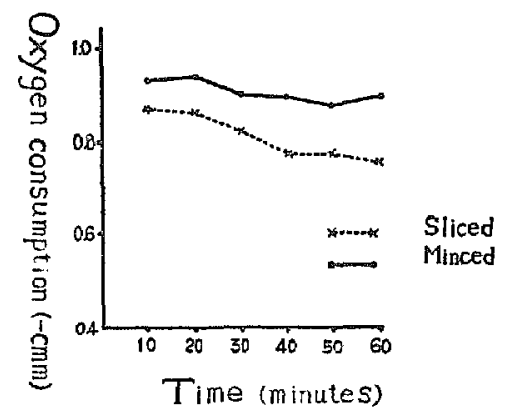

糊着することによるものかと考省られる，以上の

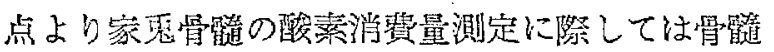
を細切しこれを㲘渴狀となして浮遊せしめるよ り，团片之なして浮避せしめる方法分一層優れた ものであると云うことが出来る。

(2) 浮遊液の種類に關する賽騟

Deutsch, Wagenfeld は赤血球の呼吸において 燐酸塩液の酸素消費抑制作用を認め, 又津田は家

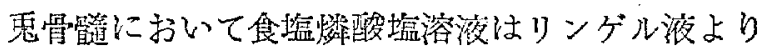
$\mathrm{Qo}_{2}$ が低值であるが測定值に動摇が少ないと迅べ ている。私達は同一家雭骨酭沁つい前述の切片 をリンゲル重曹腹, 食塩燐酸塩液, タイロード液の 3 種の浮避液に浮遊せしめた場合の酸素消費量を 比較檢訶した。13例の平均はリンダル重曹湺5.06

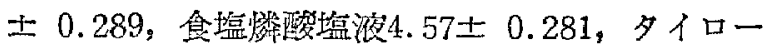
ド液4. 54 土 0.319 で撒有度は食塩哖睃壏波が最も

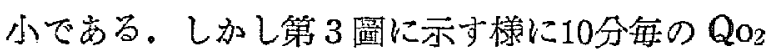
を比畭するとリンゲル重曹液が最も動摇少をく,

Fig. 3 Comparison of Oxygen consumption in 3 different suspension-medium every 10 minutes (Average of 15 rabbits)



他の液は持間の經過と共に著しく低下の傾问 示す。文平均値を統訐學的に檢討するとリンゲル

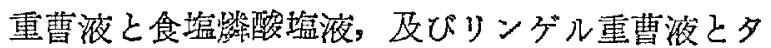
イロート゚液の間には明办に有意の差が認められる が，二れに反して食塩躍酸塩液とタイロード没の

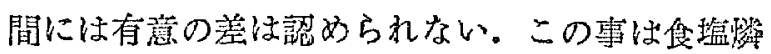
酸塩液及びタイロード液中の掺酸塩が呼吸作用に 路して抑制的に慟くもの認められる。

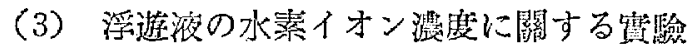
各種の組維について諸芜は組織呼吸に及ほ文浮 遊液の水素イオン漫度の影響を检索しているが， 骨䯕に關しては未報告をみない，私達は家鬼骨

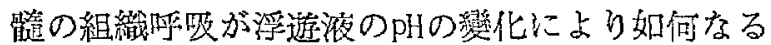
態度をとるか子觀察するため食塩燐酸塩液にてそ の燃酸塩の敖合を Serönsen に從つて變元， pH $6.3 ， 6.8 ， 7.4 ， 7.7,8.006$ 種頪の浮括液 を作成し，そのそれそれに同一家雭骨敖盖を浮遊せ しめその Q0zを測定した。

第4, 5 圆の如く $\mathrm{QO}_{2}$ の平均值はpH 7.4kおいて 最も大で $7.4>7.1>7.7>8.0>6.8>6.30$ 順に漸次減少する．文第 4 圖にみられる樣に浮遊

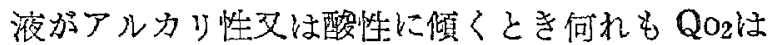
抑制せられるが，アルカリ性に傾く時は酸性に傾 く時に地してその抑制度は少ない。次にpH 7.4を 中心として各pHにおける $\mathrm{QO}_{2}$ を比较すると $\mathrm{pH} 7.1$ この間に愦差範圍内にあり，他のpH浮遊液との間

Fig. 4 Oxygen consumption in various Suspension medium $\mathrm{pH}$ (Average of 13 rabbits)

40

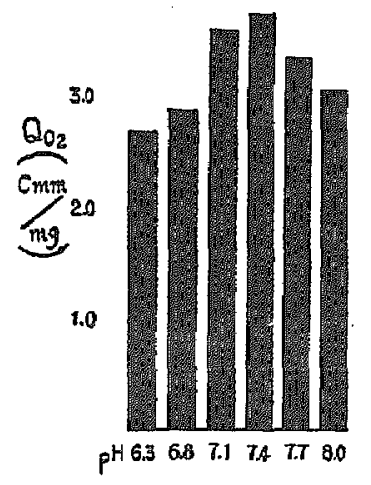


Fig. 5 Oxygen consumption of every 10 minutes in saline phosphate solutions of various $\mathrm{pH}$ (Average of 13 rabbits).

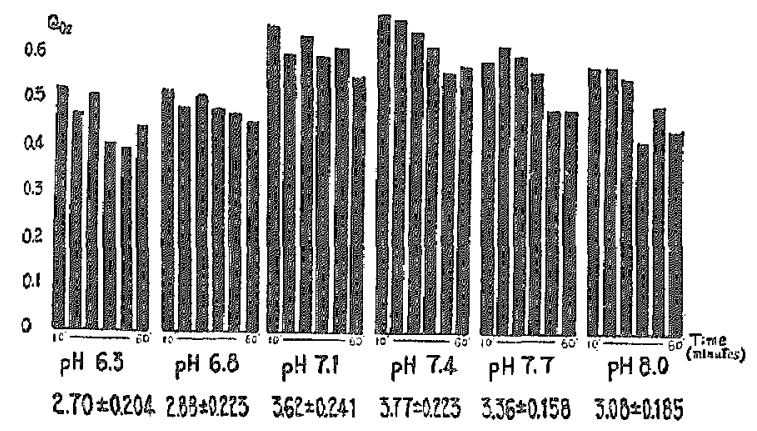

にはすの゙て有意の差公認められた。

更に各種阬浮避液中に㧍ける每10分酸素消熼量

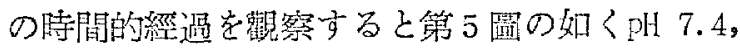
7.1 に比してこ社等より酸性及びアルカリ性側何

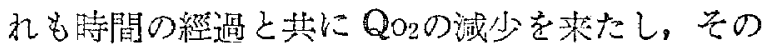
減少度は酸性側において甚しいことが諗められ t.

\section{III 臨店的䌞索}

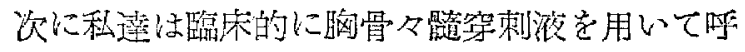

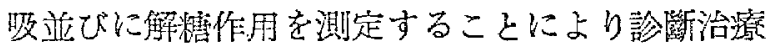
面への應用忞試みている。臨床面方らの報告は Schretzenmayr, Bröcheler(1936), Bock, Felix (1940)以来 $2 \sim 3$ の锧告のみで，未だ系統的なも のをみい。

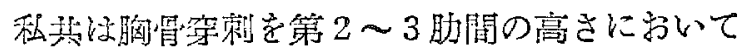
内噰 $1.2 \mathrm{~mm}$ の穿刺針を用いて行い, 正確に $0.3 \mathrm{cc}$ を採取した。第刺液に0.1\%のへパリン1滴を添 加し有櫓細胞数計算，塣抹標本作成の後メスピペ ットにて 0.2ccを吸引し直ちに Warburg 檢压裴 置に加け，破素消費量測定は Warburg 直接法に

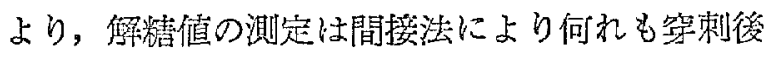
30分で豫䚚振とうを開始した。尚啋取材料の關俰

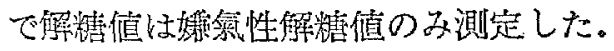

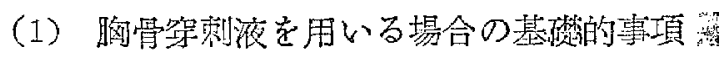

A.胸骨穿刺方法已呼吸解粠值

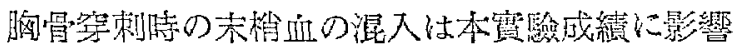
が大きいもの之考えられる分上記諸家は採取液量 が不定で㐫る。私達は骨檤穿刺の方法は服部・僣
野の穿刺法に從い，吸引力，吸引液量には特に意 を用いた。猪里の成繢によると $1 \mathrm{cc}$ 採取の場合は $0.2 \mathrm{cc}$ 採取に比して有模細胞數は $1 / 2.5 に$ 減少し， 及大咬引によるときは有核細施數艻小吸引に比し て約 5 倍上なつている。私共は来梢血の混入を最 大限度に避りるた的許される籍图の $0.3 \mathrm{cc}$ を大吸 引法により採取し，ての $0.2 \mathrm{cc}$ 测定に傼用した が，尚饮の如き垻蜸をも試みた。

(a) 採取淮量之呼吸值

前記大吸引法により採取液量の相異による哦咬

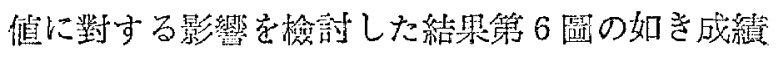

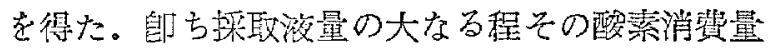

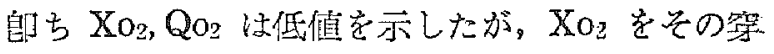
刺液 $1 \mathrm{cmm}$ 中の有核細胞數で除した值師っ $\mathrm{Xo}_{2}$ I $\mathrm{K}$ は圆の如く吸引液量の差によつて著變さ認めな

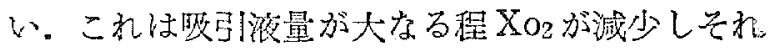
に應じて有橯細跑數も減少するからである。

Fig. 6 The change in oxygenconsumption by the suctional volume.

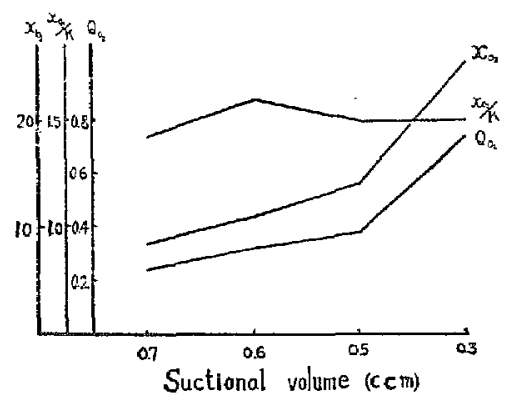

(b) 同一穿刺孔において連續 2 回吸引せる場 合の呼吸解糖值

津田は吸引量と有核細胞慗の關䋆を檢するため に，第 1 回等剌吸引後同一場所にて注射器のみを 取換えて更に種々量を哽引儿，細胞數の變化をみ ている。社共は第1，2表の様に同一穿刺孔より連 續 2 包 $0.3 \mathrm{cc}$ 宛吸引儿その有核細胞數之呼颔值並

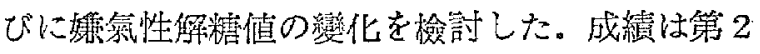

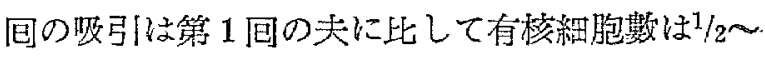

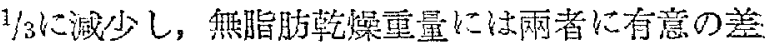

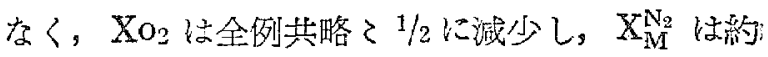
2/3に減少を示した。自亏解精作用に比して酸素消 
Tab. 1 Oxygen consumption of the punctate taken by two

Succesive Suction from the same sternal puncture.

\begin{tabular}{|c|c|c|c|c|c|c|c|c|c|c|c|c|}
\hline \multirow{3}{*}{ Name } & \multirow[b]{2}{*}{ Age } & \multirow[b]{2}{*}{ Sex } & \multicolumn{5}{|c|}{ Ist Suction $0.3 \mathrm{cc}$} & \multicolumn{5}{|c|}{ 2nd Suction $0.3 \mathrm{ec}$} \\
\hline & & & $\begin{array}{l}\text { Number } \\
\text { of nucle- } \\
\text { ated cells } \\
\text { of bone } \\
\text { marrow } \\
\left(\times 10^{4}\right)\end{array}$ & $\begin{array}{c}\text { Fat free } \\
\text { dry } \\
\text { weight } \\
\text { (mg) }\end{array}$ & $\mathrm{Xo}_{2}$ & $\mathrm{Xo}_{2} / \mathrm{K}$ & $\mathrm{Qo}_{2}$ & $\begin{array}{c}\text { Number } \\
\text { of nucle- } \\
\text { ated cells } \\
\text { of bone } \\
\text { marrow } \\
\left(\times 10^{4}\right)\end{array}$ & $\begin{array}{c}\text { Fat free } \\
\text { dry } \\
\text { weight } \\
\text { (mg) }\end{array}$ & $\mathrm{Xo}_{2}$ & $\mathrm{Xo}_{2} / \mathrm{K}$ & $\mathrm{QO}_{2}$ \\
\hline & 23 & 3 & 23.7 & 27.2 & 31.68 & 1.34 & 1.16 & 6.26 & 38.0 & 14.24 & 2.28 & 0.37 \\
\hline & 25 & $\delta$ & 24.82 & 35.0 & 29.75 & 1.18 & 0.85 & 9.26 & 38.2 & 16.29 & 1.75 & 0.48 \\
\hline & 35 & 우 & 18.70 & 25.1 & 17.5 & 0.93 & 0.70 & 6.34 & 29.3 & 14.08 & 2.22 & 0.48 \\
\hline & 53 & $\hat{o}$ & 5.2 & 35.0 & 15.81 & 3.04 & 0.45 & 3.14 & 38.3 & 8.59 & 2.70 & 0.22 \\
\hline & 19 & $\hat{\delta}$ & 14.14 & 30.0 & 13.18 & 0.93 & 0.44 & 4.76 & 26.5 & 8.15 & 1.50 & 0.31 \\
\hline & 19 & $\delta$ & 20.70 & 38.6 & 32.04 & 1.55 & 0.83 & 11.56 & 41.2 & 16.40 & 1.43 & 0.40 \\
\hline & 35 & 우 & 2.10 & 34.1 & 15.21 & 7.24 & 0.45 & 1.37 & 29.7 & 2.55 & 1.86 & 0.09 \\
\hline Average & & & $\begin{array}{r}15.62 \\
\pm 3.12\end{array}$ & $\begin{array}{r}32.14 \\
\pm 1.55\end{array}$ & $\begin{array}{r}22.16 \\
\pm 2.81\end{array}$ & $\begin{array}{r}2.31 \\
\pm 0.68\end{array}$ & $\begin{array}{r}0.70 \\
\pm 0.09\end{array}$ & $\begin{array}{r}4.67 \\
\pm 1.32\end{array}$ & $\begin{array}{r}34.47 \\
\pm 2.01\end{array}$ & $\begin{array}{r}11.47 \\
\pm 1.67\end{array}$ & $\begin{array}{r}1.96 \\
\pm 0.16\end{array}$ & $\begin{array}{c}0.34 \\
\pm 0.054\end{array}$ \\
\hline
\end{tabular}

Tab. 2 Glycolysis of the punctate taken by two Succesive Suction fron the same sternal puncture.

\begin{tabular}{|c|c|c|c|c|c|c|c|c|c|c|c|c|}
\hline \multirow[b]{2}{*}{ Name } & \multirow[b]{2}{*}{ Age } & \multirow[b]{2}{*}{ Sex } & \multicolumn{5}{|c|}{ 1st Suction $0.3 \mathrm{cc}$} & \multicolumn{5}{|c|}{ 2nd suction $0.3 \mathrm{ce}$} \\
\hline & & & $\begin{array}{c}\text { Number } \\
\text { of nucle- } \\
\text { ated cells } \\
\text { of bone } \\
\text { marrow } \\
\left(\times 10^{1}\right)\end{array}$ & $\mid \begin{array}{c}\text { Fat free } \\
\text { dry } \\
\text { weight } \\
\text { (mg) }\end{array}$ & $\mathrm{X}_{\mathrm{M}}^{\mathrm{N}_{2}}$ & $\mathrm{X}_{\mathrm{M}}^{\mathrm{N}_{2}} / \mathrm{K}$ & $\mathrm{Q}_{\mathrm{M}}^{\mathrm{N}_{2}}$ & $\begin{array}{c}\text { Number } \\
\text { of nucle- } \\
\text { ated cells } \\
\text { of bone } \\
\text { marrow } \\
\left(\times 10^{4}\right)\end{array}$ & $\begin{array}{c}\text { Fat free } \\
\text { dry } \\
\text { weight } \\
\text { (mg) }\end{array}$ & $\mathrm{X}_{\mathrm{M}}^{\mathrm{N}_{2}}$ & $\mathrm{X}_{\mathrm{M}}^{\mathrm{N}_{2} / \mathrm{K}}$ & $\mathbf{Q}_{\mathrm{M}}^{\mathrm{N}_{2}}$ \\
\hline & 46 & 우 & 3.22 & 32.4 & 12.81 & 4.00 & 0.40 & 1.26 & 32.5 & 8.55 & 6.78 & 0.26 \\
\hline & 64 & $\delta$ & 4.54 & 32.6 & 12.90 & 2.82 & 0.40 & 1.36 & 33.9 & 10.08 & 7.41 & 0.30 \\
\hline & 36 & 9 & 16.36 & 26.5 & 42.14 & 2.57 & 1.60 & 6.42 & 30.7 & 23.52 & 3.66 & 0.77 \\
\hline & 24 & 8 & 7.16 & 32.4 & 30.10 & 4.20 & 0.93 & 3.68 & 27.0 & 21.00 & 5.71 & 0.78 \\
\hline & 52 & 우 & 21.66 & 30.8 & 40.28 & 1.86 & 1.31 & 14.16 & 30.0 & 32.76 & 2.31 & 1.09 \\
\hline & 56 & $\delta$ & 11.58 & 34.1 & 18.00 & 1.55 & 0.53 & 6.92 & 35.2 & 17.3 & 2.48 & 0.49 \\
\hline & 40 & 3 & 5.60 & 23.1 & 14.62 & 2.61 & 0.63 & 2.92 & 30.0 & 11.38 & 3.90 & 0.38 \\
\hline Average & & & $\begin{array}{r}10.02 \\
\pm 2.40 \\
\end{array}$ & $\begin{array}{r}30.27 \\
\pm 1.58 \\
\end{array}$ & $\begin{array}{r}24.41 \\
\pm 4.52 \\
\end{array}$ & $\begin{array}{r}2.80 \\
\pm 0.93 \\
\end{array}$ & $\begin{array}{r}0.83 \\
\pm 0.15 \\
\end{array}$ & $\begin{array}{r}5.25 \\
\pm 1.59 \\
\end{array}$ & $\begin{array}{r}31.32 \\
\pm 2.26 \\
\end{array}$ & $\begin{array}{r}17.80 \\
\pm 3.04 \\
\end{array}$ & $\begin{array}{r}4.61 \\
\pm 0.73 \\
\end{array}$ & $\begin{array}{r}0.58 \\
\pm 0.07 \\
\end{array}$ \\
\hline
\end{tabular}

費量の減少の方が甚だしい. 無脂肪乾燥重量には 著變がないから $\mathrm{Qo}_{2}, \mathrm{Q}_{\mathrm{M}}^{\mathrm{N}_{2}}$ は $\mathrm{XO}_{2}, \mathrm{X}_{\mathrm{M}}^{\mathrm{N}_{2}}$ と同様の傾 向を示すが,一方 $\mathrm{Xo}_{2} / \mathrm{K}, \mathrm{X}_{\mathrm{M}}^{\mathrm{N}_{2}} / \mathrm{K}$ についてみると， $\mathrm{X} 02 ， \mathrm{X}_{\mathrm{M}}^{\mathrm{N}_{2}}$ は第 2 包目に減少し且つ有核細胞數も 第 2 回目に減少するから $\mathrm{Xo}_{2} / \mathrm{K}$ については有焚 細胞數の減少度と $\mathrm{Xo}_{2}$ の減少展が大体並行的であ るため第 1 回と第 2 回吸引液の間に有意の差を認 めない。一方 $\mathrm{X}_{\mathrm{M}}^{\mathrm{N}_{2}} / \mathrm{K}$ は有核細胞數の減少度に比し て $\mathrm{X}_{M}^{N_{2}}$ の減少度が小であるために第 2 国目吸引 の方唯 1 第目吸引よ日大となつた。即ち要する に第 2 回目吸引においては有核細胞稘の減少，末
梢血混入, 細胞障害等の諸因子が考えられるが,こ れら諸因子の影響が呼吸作用に對する場合と様氮 性解楉作用に對する場合で異なることを認めた。

\section{B. 健康人胸骨穿刺液の呼吸解猜值}

末梢血のみならず骨䯕像にも全然異常を認めな い健康人について, 前远の如き第刺吸引液 $0.3 \mathrm{cc}$ 中の $0.2 \mathrm{cc}$ の呼吸並びに㐮氮性解䅯值を湘定し, 第3，4表の如き成績を得た。

C. 胸骨穿刺液の無脂肪乾燥重量と有核細胞數 との閣係。

穿刺液中の有核細胞數と篦脂肪乾燥重量は兩者 
Tab. 3 Oxygen consumption of normal persons.

\begin{tabular}{|c|c|c|c|c|c|c|c|}
\hline Name & Age & sex & $\begin{array}{c}\text { Number of } \\
\text { nucleated cells } \\
\text { of bone marrow } \\
\left(\times 10^{4}\right)\end{array}$ & $\begin{array}{c}\text { Fat free } \\
\text { dry weight } \\
(\mathrm{mg})\end{array}$ & $\mathrm{Xo}_{2}$ & $\mathrm{Xo}_{2} / \mathrm{K}$ & $\mathrm{QO}_{2}$ \\
\hline & 28 & $\hat{\hat{\sigma}}$ & 10.2 & 38 & 22.6 & 2.22 & -0.59 \\
\hline & 28 & $\$$ & 10.6 & 47 & 21.2 & 2.00 & -0.45 \\
\hline & 34 & $\delta$ & 27.9 & 36 & 27.2 & 0.97 & -0.75 \\
\hline & 23 & $\delta$ & 17.5 & 31 & 19.0 & 1.09 & -0.61 \\
\hline & 26 & 9 & 9.0 & 34 & 20.1 & 2.23 & -0.59 \\
\hline & 24 & $\delta$ & 28.4 & 46 & 39.4 & 1.39 & -0.85 \\
\hline & 40 & 웅 & 24.0 & 33 & 30.8 & 1.28 & -0.93 \\
\hline & 21 & 웅 & 10.8 & 33 & 25.5 & 2.36 & -0.90 \\
\hline & 23 & $t$ & 23.7 & 27.2 & 31.68 & 1.34 & -1.16 \\
\hline & 25 & $\$$ & 24.82 & 35 & 29.75 & 1.18 & -0.85 \\
\hline & 35 & q & 18.7 & 25.1 & 17.5 & 0.93 & -0.70 \\
\hline & 19 & 3 & 14.14 & 30 & 13.13 & 0.93 & -0.44 \\
\hline & 19 & 3 & 20.70 & 38.6 & 32.04 & 1.55 & -0.83 \\
\hline Average & & & $18.50 \pm 2.50$ & $34.9 \pm 2.30$ & $25.38 \pm 2.99$ & $1.50 \pm 0.21$ & $0.74 \pm 0.08$ \\
\hline
\end{tabular}

Tab. 4 Glycolysis of normal persons.

\begin{tabular}{|c|c|c|c|c|c|c|c|}
\hline Name & Age & Sex & $\begin{array}{c}\text { Number of } \\
\text { nucleated cells } \\
\text { of bone marrow } \\
\left(\times 10^{4}\right)\end{array}$ & $\begin{array}{l}\text { Fat free } \\
\text { dry weight } \\
\text { (mg) }\end{array}$ & $\mathrm{X}_{\mathrm{M}}^{\mathrm{N}_{2}}$ & $\mathrm{X}_{\mathrm{M}}^{\mathrm{N}_{2}} / \mathrm{K}$ & $\mathrm{Q}_{\mathrm{M}}^{\mathrm{N}_{2}}$ \\
\hline & 28 & $\hat{o}$ & 8.44 & 36 & 26.33 & 3.12 & 0.73 \\
\hline & 22 & 우 & 9.4 & 29 & 21.85 & 2.32 & 0.75 \\
\hline & 20 & 우 & 26.6 & 32 & 32.20 & 1.21 & 1.01 \\
\hline & 22 & $\delta$ & 11.12 & 38 & 22.7 & 2.04 & 0.60 \\
\hline & 22 & $\hat{0}$ & 10.92 & 47 & 23.5 & 2.15 & 0.50 \\
\hline & 36 & ㅇ & 16.36 & 26.5 & 42.14 & 2.57 & 1.60 \\
\hline & 24 & 5. & 7.16 & 32.4 & 30.10 & 4.20 & 0.93 \\
\hline & 52 & 우 & 21.66 & 30.8 & 40.28 & 1.86 & 1.31 \\
\hline & 56 & 3 & 11.58 & 34.1 & 18.00 & 1.55 & 0.53 \\
\hline & 40 & $\hat{3}$ & 5.60 & 23.1 & 14.62 & 2.61 & 0.63 \\
\hline Average & & & $12.88 \pm 2.40$ & $32.90 \pm 2.38$ & $27.17 \pm 3.24$ & $2.36 \pm 0.30$ & $0.95 \pm 0.16$ \\
\hline
\end{tabular}

Fig. 7 Nuber of nucleated calls and fat free dry weight.

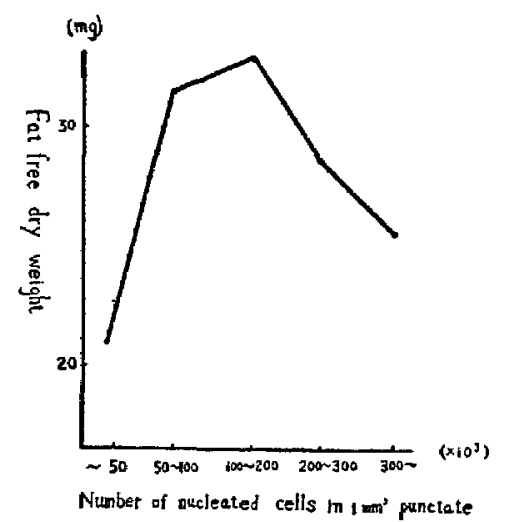

必ずしも並行的ではなく第 7 圖の様に有核絊胞數 が健康人の籍圍内にある場合汇最も大なる乾缲重 量値を示し有核細胞數がそれより多くても少なく ても即ち病的となる倾って重量は却って減少す る.

津田は $\mathrm{Xo}_{2}$ を有核細胞數にて除した値を $\mathrm{KQ}$ と して重視した。私達は $\mathrm{X}_{02} ， \mathrm{X}_{\mathrm{M}}^{\mathrm{No}}$ を津田と同じく

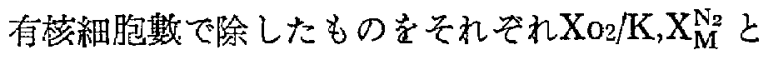
した.

私達の成績によ礼ば有核細胞數の多いもの必ず しも無脂肪乾燥重量大ならず, 從つて容積を基調 
と文る $\mathrm{Xo}_{2}, \mathrm{X}_{\mathrm{M}}^{\mathrm{N}}$ と有核細胞數を基調とする $\mathrm{Xo}_{2} / \mathrm{K}$,

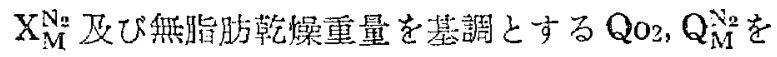
綵合的に檢討することが必要である。

（2）各匭疾患患者胸骨窎刺滩の呼吸解悟值

A. 小赤血球性低色素性分血

(a) 本熊性低色素性筫面

津田は 1 例の本症で路䋣消留量の低下を報告し ているが，私達の15例平埪の呵吸值では Xo2，

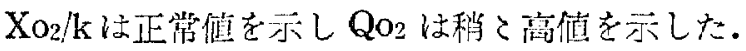
13例の解糖値ではすへて可成の高值を示した。郎 ち本症では呼吸能は砣ぞ 正常若しくは稍々充進 し，解糖能注全般的な㠵進が明膫に㑇的られた。 尚治療後正常に回復するのが見られる。

(b) バンチ氏淀候群

津田は1例の本症で酸素消䩀量の低下を報告し ている.私達は本症の5例で呼吸值は正常若しく

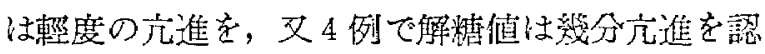
めた.

(c) 慢性失血性貧血

赤血球柔機能の充進により當然呼吸值の上昇が

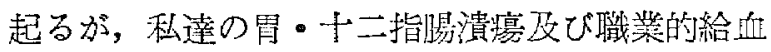
者筫血 2 例で海解粕値の充進を認め，7例の呼吸

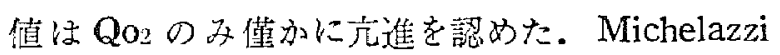
は少量失血を繰り遮す之動物の抵抗力により酸素 消費量の堌加することもあり，文減少することも あると迅へてているが，失血の反復により或時期に は乎吸現象の低下することもあると考えられる。

(d) 鉤虫症

Fig. 8 Oxygen consumption and glycolysis of microcytic anemia.

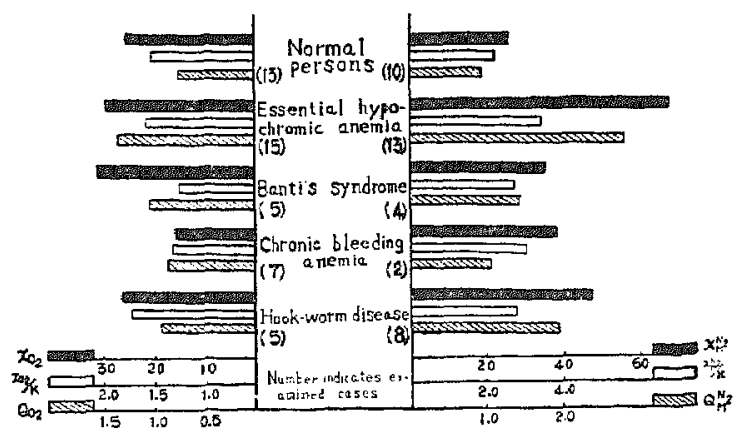

5 例につき呼吸值を，8例につき解糖值を检索 した結果烀吸值には殆ど暴常なく, 解洼値は蹬度 のて進を示した。

以上小赤血球性低色素性筫血の一群においては 第 8 圆の様に各疾患共呼吸機能には著變なく解糖 機能の儿進が認められた。

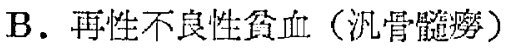

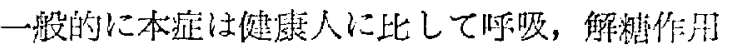
其落明に氐下寸る。本症の各病型についてみると 符 9,10圆の如く，呼哽值は血球抑留型が最も低下

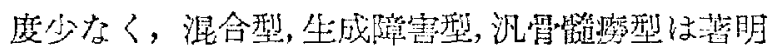

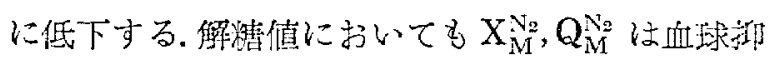
留型方最も低下度少なく, 生成障害型及び混合型 となるに從つて低下度が蒛しい，尚本症に於いて

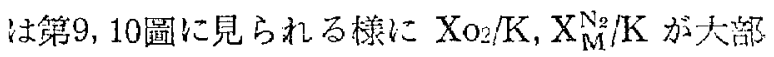

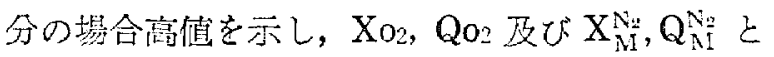

Fig. 9 Oxygen consumption of various leukemia and hypoplastic anemia.

Leukemic

Hypoplastic anemia

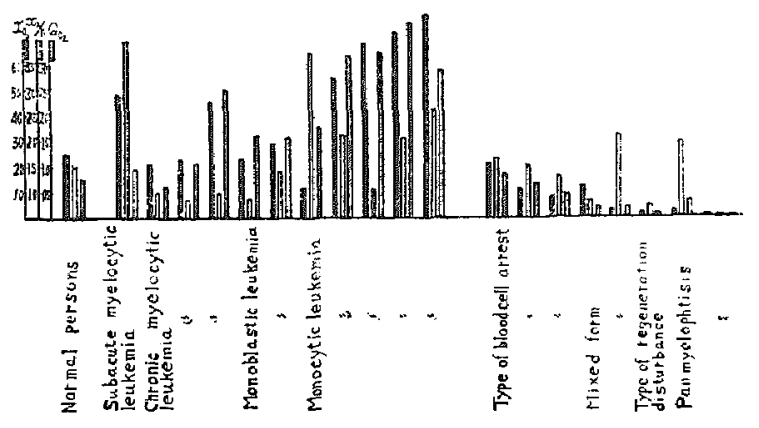

Fig. 10 Glycolysis of various leukemia and hypopiastic anemia.

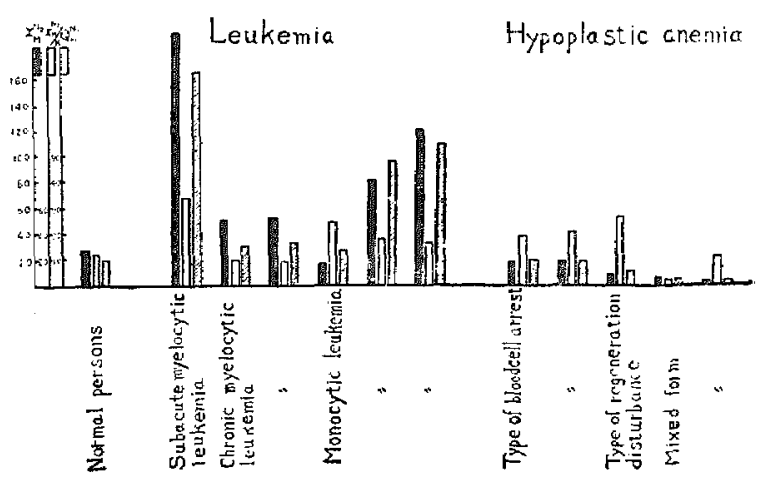




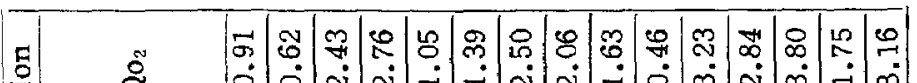



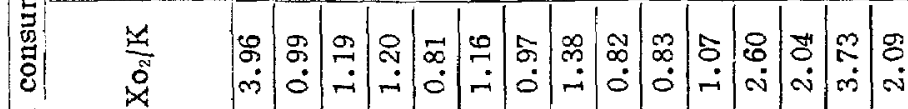

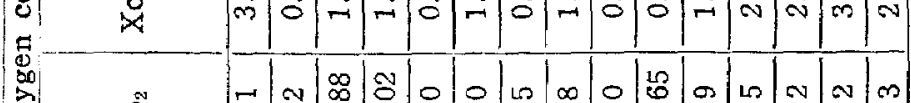

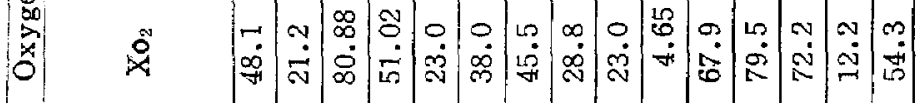




m| 莺

耳,

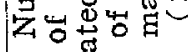

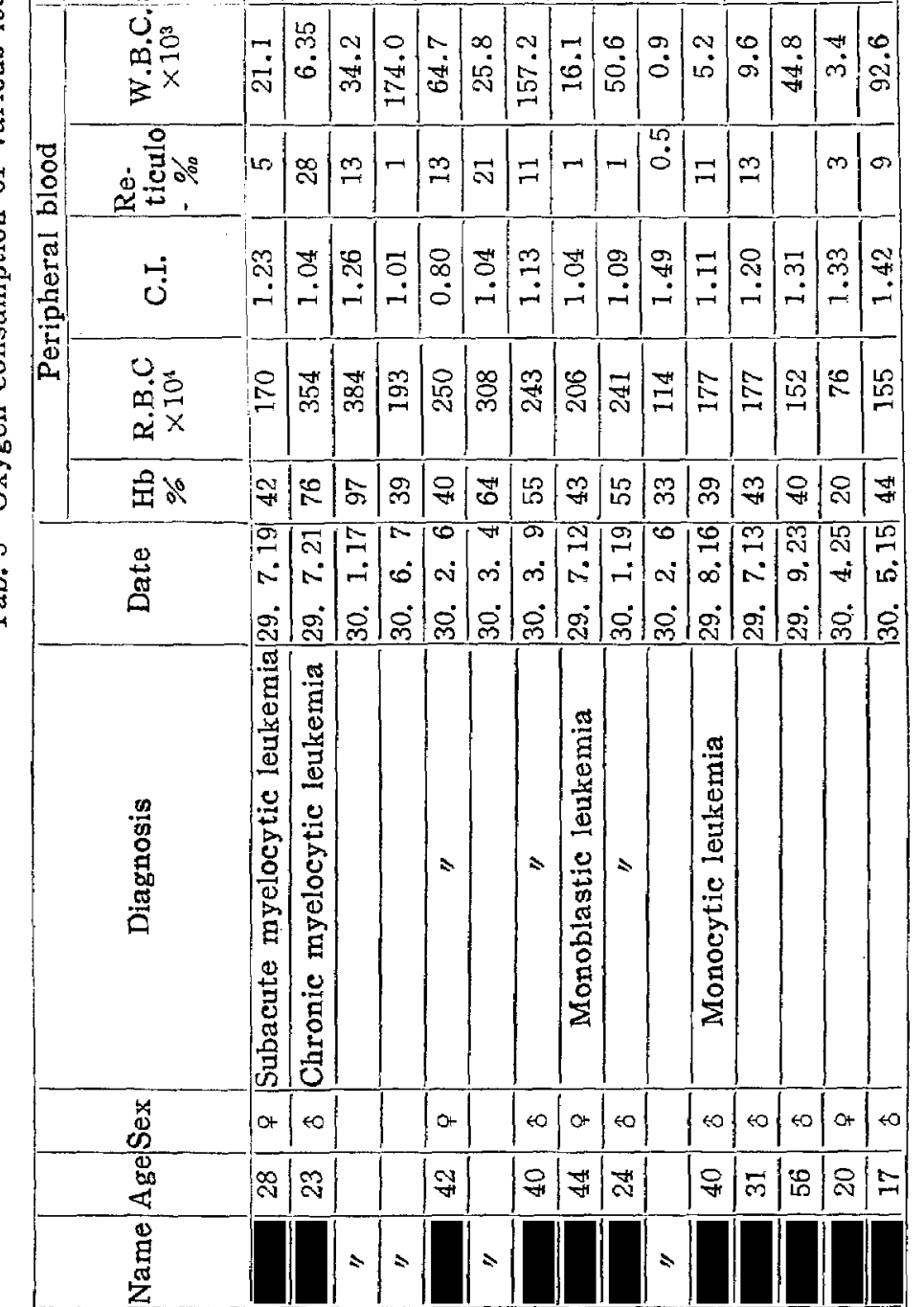

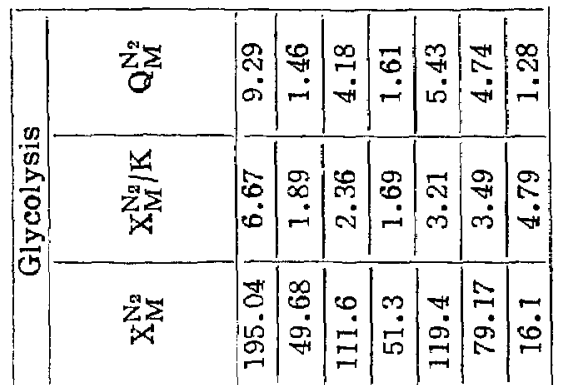
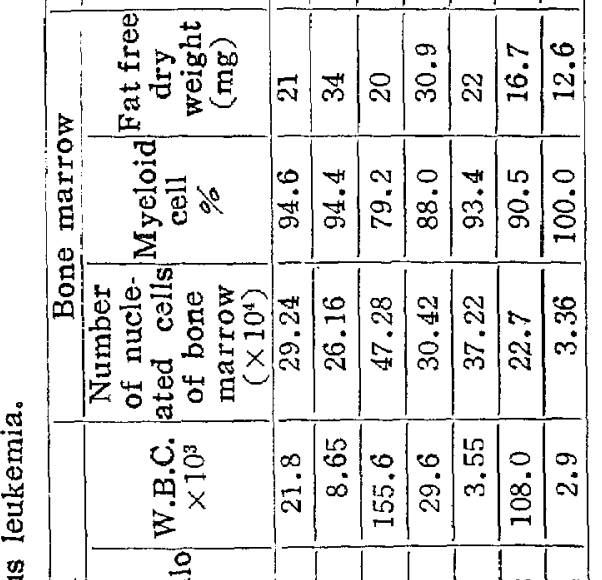

言

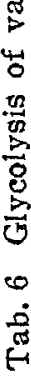

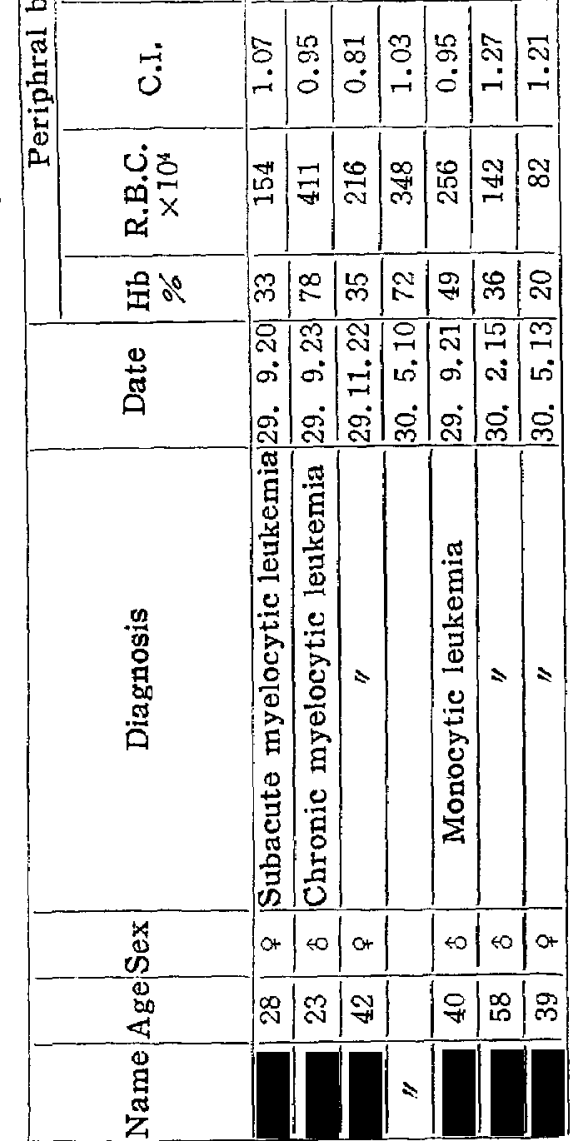



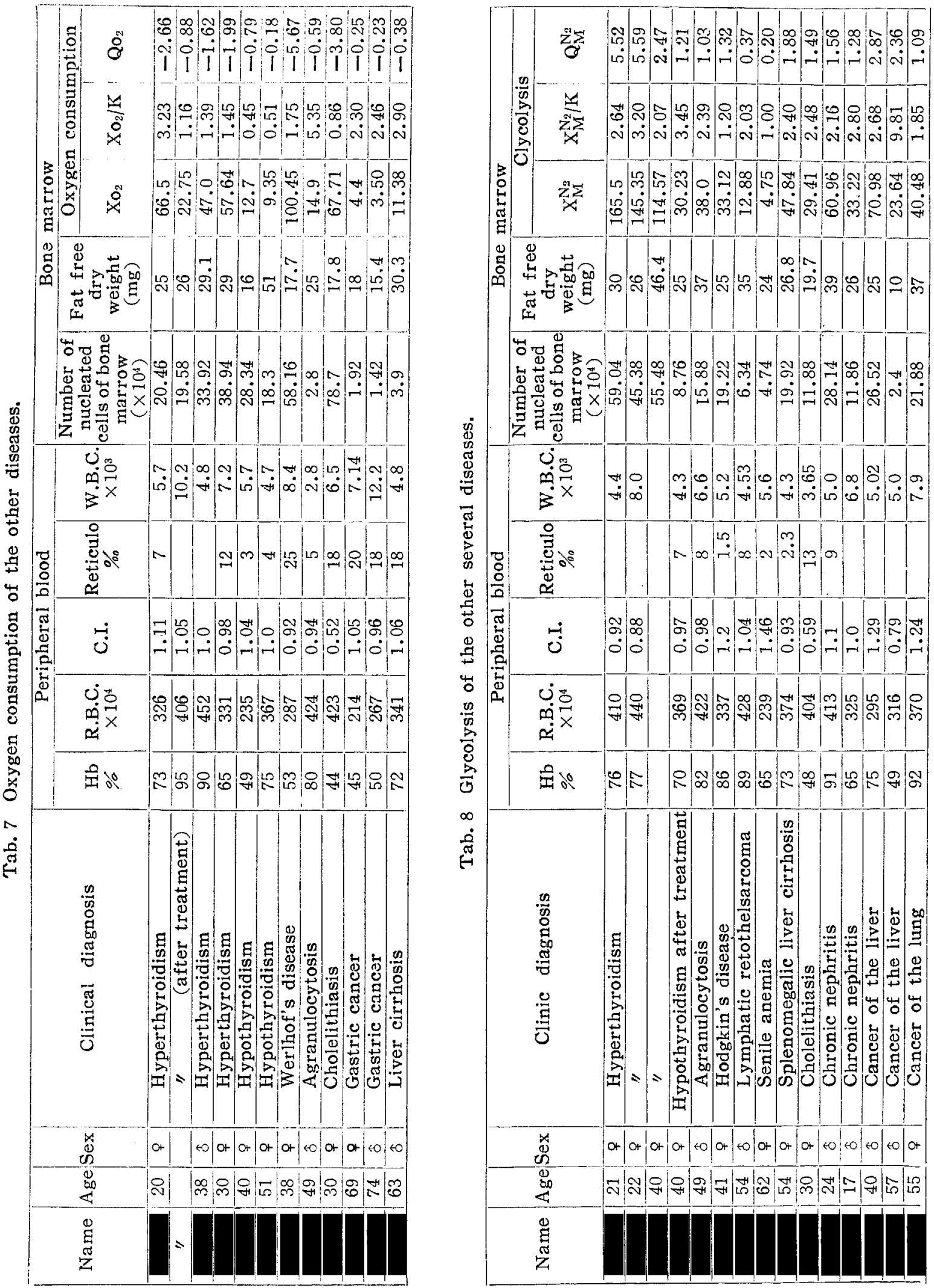


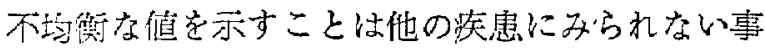
で㟧り，白血病において区對に $\mathrm{Xo}_{2} / \mathrm{K} 、 \mathrm{X}_{\mathrm{M}}^{\mathrm{N} /} / \mathrm{K}$ が 低推を示卞事独多い事實と對照的であり興味ある 瑟筫である。

C. 自血病 :

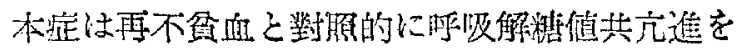
示す.

第 9,10 圆及び第 $5 ， 6$ 表の如く單球白血病は呼吸

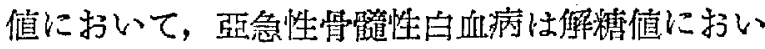
て他に例をみない程の高値を認めた．單球白血病 に比して單芽球白血病は呼吸值稍く低くこれは細

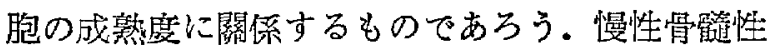
白血病では $\mathrm{Xo} / \mathrm{K}$ の低下と解糖值の全般的な上 昇が認められた。尚前述の如く白血病に對しては $\mathrm{Xo} / \mathrm{K}, \mathrm{X}_{\mathrm{M}}^{\mathrm{N}_{2}} / \mathrm{K}$ の絶對的並びに相對的減少が特異 的である.

從来白血病の末梢血について血球細胞が惡性 腫嫁型であるか或は正常幼若細胞型であるかに關 し Barron, Harrop, Soffer, Wintrobe, Remmele などの研究は何れも，健康人，感染症など の白血球増多症及び白血病の白血球の間に物質代 謝的相異が見られないと远べている.永并は霄䯣 性白血病 3 例にQ $\mathrm{Q}_{2}$ の低下と $\mathrm{Q}_{\mathrm{M}}^{\mathrm{N}_{2}}$ の上昇を認奻 ている。

Craig, Basset, Salter は Succinate 及び pPhenylendiamin を加えたときの酸素消費量に及

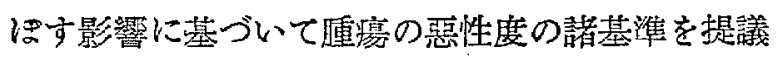
しWarrenはこれを白血病骨慥組織に用いたが價 值がなく一般的應用は寲問であると結論した。本 症の物筫代謝に關しては不明の点が多いが, 私達

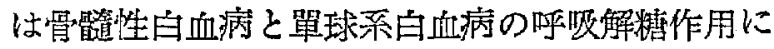
對する態度の相異はおのおのの細胞が異なつた起 源考持つ事に基づくものと考える. 又再不貧血と 白血病の檤はそれそれれ特異であり兩者の鑑別に資 することが出来る。

D. 其他の疾患

其他の疾患の少數例を第7，8表に示す，興味あ る点はバセドウ氏病では呼吸解糖值共著明に上景
し，粘液水腫では呼吸值は低下した。粘液水腫の 解糟值は幾分上昇を示したが之は本症例が甲狀腺 泖による治潦中であつたため长の影響が考光られ

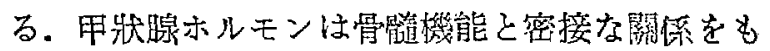
ちその機能低下症では骨瞳機能の低下を招来する ものと認めるれる。

\section{IV 結 論}

私達は正常㒸雭について2本のグレーフェ氏刀 で厚さ 0.5 m以下の骨體切片を作り, 鼣切細分し たものより一定且つ大なる呼吸值を得, 浮遊液は リンゲル重曹液において時間の經過に龂して一定 且つ大なる值を得た。

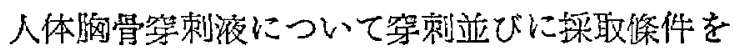
一定にすることにより臨床的應用を行なつた。本

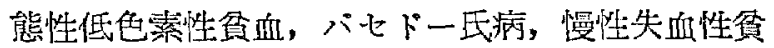
血, 鈎虫症等では呼吸值は正常又は輕度の元進 を，解狔値は元進を認めな。

再不貧血では全般的に挐吸解糖值の低下を謥 め，更に各病型との關孫は具酷造血機能の態度が

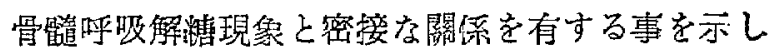
た。

白血病で汇單球白血病の呼吸能の進特に璱し く, 解糖能も可成り充進を諗內, 骨䯘性白血病で は呼吸能よりも解糖能の㠵進が明膫である. 又白 血病已再不盆血の $\mathrm{Xo}_{2} / \mathrm{k}, \mathrm{X}_{\mathrm{M}}^{\mathrm{No}} / \mathrm{K}$ 江专れそれ特異 である、以上の点上り骨䯣の㭔吸鱀糖作用は造血 の生理及び病理の檢索や貧血の鑑品診衒に资する ことが出来る。

\section{文 献}

1）津田：內科璸函，2，1，昭和 30. -2）永井：日 㐫會誌, 43, 822, 昭和 30. - 3) Bréza: Arch. f. exp. Path. Pharm. 117:240, 1926. -4) Barron. Harrop: Jour. biol. Chem. 84:89, 1929. -5) Worren: Amer. Jour. pey. 110:61, 1934. -6) Schretzenmayr. Bröcheler: Kl Wschr. 15:998, 1936. -7) Orr. Stickland: Biol. Jour. 32:567, 1938. -8)Bock. Felix: Z. f. ges. exp. Med. 107 : 167, 1940. -9) Warren: Cancer Research 3: 621, 1943. -10) Remmele: Acta haemat. 13: $103,1955$.

[受稿・昭和30年 7 月13日] 